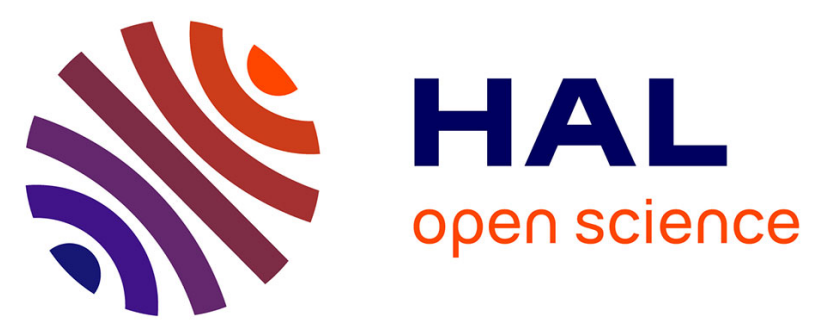

\title{
Brain histamine and schizophrenia: potential therapeutic applications of H3-receptor inverse agonists studied with BF2.649.
}

Xavier Ligneau, Laurent Landais, David Perrin, Johanne Piriou, Marilyne

Uguen, Emmanuel Denis, Philippe Robert, Régis Parmentier, Christelle Anaclet, Jian-Sheng Lin, et al.

\section{To cite this version:}

Xavier Ligneau, Laurent Landais, David Perrin, Johanne Piriou, Marilyne Uguen, et al.. Brain histamine and schizophrenia: potential therapeutic applications of H3-receptor inverse agonists studied with BF2.649.. Biochemical Pharmacology, 2007, 73 (8), pp.1215-24. 10.1016/j.bcp.2007.01.023 . inserm-00150117

\section{HAL Id: inserm-00150117 https://www.hal.inserm.fr/inserm-00150117}

Submitted on 9 Aug 2007

HAL is a multi-disciplinary open access archive for the deposit and dissemination of scientific research documents, whether they are published or not. The documents may come from teaching and research institutions in France or abroad, or from public or private research centers.
L'archive ouverte pluridisciplinaire HAL, est destinée au dépôt et à la diffusion de documents scientifiques de niveau recherche, publiés ou non, émanant des établissements d'enseignement et de recherche français ou étrangers, des laboratoires publics ou privés. 


\section{Title}

\section{Brain histamine and schizophrenia: potential therapeutic}

\section{applications of $\mathrm{H}_{3}$-receptor inverse agonists studied with BF2.649.}

\section{Authors:}

Xavier Ligneau ${ }^{\mathrm{a}}$, Laurent Landais ${ }^{\mathrm{a}}$, David Perrin ${ }^{\mathrm{a}}$, Johanne Piriou ${ }^{\mathrm{a}}$, Marilyne Uguen ${ }^{\mathrm{a}}$,

Emmanuel Denis ${ }^{\mathrm{a}}$, Philippe Robert ${ }^{\mathrm{a}}$, Régis Parmentier ${ }^{\mathrm{b}}$, Christelle Anaclet ${ }^{\mathrm{b}}$, Jian-Sheng Lin

${ }^{\mathrm{b}}$, Aude Burban ${ }^{\mathrm{c}}$, Jean-Michel Arrang ${ }^{\mathrm{c}}$, Jean-Charles Schwartz ${ }^{\mathrm{a}}$

${ }^{\text {a }}$ Bioprojet-Biotech, Saint Grégoire, France

${ }^{\mathrm{b}}$ INSERM, U628, Département de Médecine Expérimentale, Université Claude Bernard, Lyon, France

${ }^{\mathrm{c}}$ INSERM, U573, Centre Paul Broca, Paris, France

Corresponding author

Professor Jean-Charles Schwartz, 4 rue du Chesnay-Beauregard, BP96205, 35762 Saint

Grégoire Cedex, France, tel 332992804 40, fax 332992804 44, e-mail

schwartz@bioprojet.com 


\section{Running title:}

Effects of BF2.649 in murine models of schizophrenia

\section{Statistics:}
Abstract 151 words
Introduction 500 words
Discussion 918 words 


\section{Abbreviations:}

ANOVA, analysis of variance; $\mathrm{C}_{\max }$, maximal concentration; $\mathrm{AUC}$, area under the curve; CNS, central nervous system; GPCRs, G-protein coupled receptors; HPLC, high-performance liquid chromatography; LC, liquid chromatography; LC-MS/MS, liquid chromatography mass spectrometry; BF2.649, 1-\{3-[3-(4-chlorophenyl)propoxy]propyl $\}$ piperidine, hydrochloride, BF30, 1-[3-(4-chlorophenyl)propyl]-4-phenylpiperazine, hydrochloride; DOPAC, dihydroxyphenyl acetic acid; 5-HT, serotonine; 5-HIAA, 5-hydroxyindole-3-acetic acid; MK801, dilzocilpine; CPX, ciproxifan; PCP, phencyclidine; t-MeHA, tele-methylhistamine; APDs, antipsychotic drugs; LMA, locomotor activity; PPI, prepulse inhibition; EEG, electroencephalogram; EMG, electromyogram; W, wakefulness; SWS slow wave sleep; PS, paradoxical sleep; 


\begin{abstract}
BF2.649, a high affinity and selective non-imidazole histamine $\mathrm{H}_{3}$-receptor antagonist/inverse agonist, was found to easily enter the brain after oral administration to mice: it displayed a ratio of brain/plasma levels of about 25 when considering either $\mathrm{C}_{\max }$ or AUC values. At low oral doses $(2.5-20 \mathrm{mg} / \mathrm{kg})$, it elicited in mice a dose-dependent wakening effect accompanied with a shift towards high frequency waves of the EEG, a sign of cortical activation.

DOPAC/dopamine ratios were enhanced in the prefrontal cortex but not in the striatum, indicating a selective activation of a sub-population of dopaminergic neurons.

BF2.649 showed significant inhibitory activity in several mouse models of schizophrenia. It reduced locomotor hyperactivity elicited by methamphetamine or dizolcipine without significantly affecting spontaneous locomotor activity when administered alone. It also abolished the apomorphine-induced deficit in prepulse inhibition.

These observations suggest that $\mathrm{H}_{3}$-receptor inverse agonists/antagonists deserve attention as a novel class of antipsychotic drugs endowed with pro-cognitive properties.
\end{abstract}




\section{Keywords:}

Histamine $\mathrm{H}_{3}$ receptor

Inverse agonist/antagonist

BF2.649

Sleep/wake

Schizophrenia

Locomotor activity 


\section{Introduction}

Although the role of histaminergic neurons in schizophrenia and in the effects of antipsychotic drugs has been less studied than those of other aminergic neurons, the topic deserves attention. In agreement, histamine neuron activity seems to be enhanced in both rodent models of schizophrenia (changes elicited by dopamine-releasing or glutamateblocking drugs) of the human disease.

A single administration of methamphetamine markedly increases tele-methylhistamine (t-MeHA) levels, an index of histamine neuron activity, in the cerebral cortex, striatum and hypothalamus [1], a response resulting from the stimulation of histaminergic neurons by endogenous dopamine activating selectively $\mathrm{D}_{2}$ receptors. In agreement, this effect was completely blocked by haloperidol, a $\mathrm{D}_{2} / \mathrm{D}_{3}$-receptor antagonist, but remained unchanged either after administration of nafadotride used at a dose inducing a selective blockade of the $D_{3}$ receptor [2], or in the brain of mice lacking functional $D_{3}$ receptors. $D_{2}$-like receptor binding sites are detected in the tuberomammillary nucleus [3], in which $\mathrm{D}_{3}$ receptors could not be detected (J. Diaz, personal communication). Therefore, endogenous dopamine may directly activate histamine neurons by interacting with $\mathrm{D}_{2}$ receptors located upon their perikarya or dendrites [2], onto which dopamine-containing axons emanating from the ventral tegmental area or substantia nigra project [4]. $\mathrm{D}_{2}$ receptors located on histaminergic nerve endings do not seem to be involved since apomorphine fails to significantly affect histamine release from slices of rat cerebral cortex [5].

In rats or mice receiving methamphetamine repeatedly and showing locomotor sensitization, the basal activity of histaminergic neurons is persistently enhanced, presumably as a result of persistent enhancement of dopamine release onto the tuberomamillary neurons $[6,1]$ 
Phencyclidine (PCP), a non-selective "psychotogenic" NMDA receptor antagonist, significantly enhances t-MeHA levels in various mouse brain regions [7, 8]. Furthermore the effect of PCP is mimicked by MK-801, another NMDA open-channel blocker displaying higher potency and selectivity [9]. In addition, histidine decarboxylase mRNA expression is increased by PCP administration in the tuberomammillary nucleus [9].

Levels of t-MeHA are significantly elevated in the cerebrospinal fluid of patients with chronic schizophrenia [10] whereas $\mathrm{H}_{1}$ receptor-mediated responses are blunted $[11,12]$ and $\mathrm{H}_{1}$-receptor binding reduced in cortical areas of these patients [13], possibly reflecting a down-regulation of the receptor consequent to overstimulation by endogenous histamine. In addition antipsychotic drugs (APDs) affect histaminergic neurotransmission in various ways: 1 / a large number of APDs are potent $\mathrm{H}_{1}$-receptor antagonists, a feature which confers them sedative and pro-obesity side-effects, 2/ typical APDs tend to inhibit histaminergic neuron activity, whereas atypical APDs have opposite effects as a result of their 5- $\mathrm{HT}_{2 \mathrm{~A}}$ antagonism [14].

The above information suggests the interest of testing agents affecting selectively histaminergic neurotransmission in psychotic states. So far, only the (negative) effects of $\mathrm{H}_{1^{-}}$ receptor antagonists of the first generation, i.e. the brain-penetrating "antihistamines", were assessed since neither $\mathrm{H}_{2}$ - nor $\mathrm{H}_{3}$-receptor antagonists crossing the blood-brain barrier were introduced in the clinics. Since potent and selective $\mathrm{H}_{3}$-receptor antagonists/inverse agonists are now currently available for this purpose, we have addressed these questions using BF2.649 i.e. 1-\{3-[3-(4-chlorophenyl)propoxy]propyl $\}$ piperidine, a potent and selective inverse agonist at the histamine $\mathrm{H}_{3}$ receptor [15]. 


\section{Materials and methods}

\subsection{Changes in plasma and tissue levels of BF2.649 after oral administration to mice}

Male Swiss mice (25 \pm 1 g, R. Janvier, Le Genest Saint Isle, France) were dosed p.o. with $10 \mathrm{mg} / \mathrm{kg}$ BF2.649 after overnight fasting. At times of $0.5,1.5,3$ and $8 \mathrm{hr}$ post dose, $0.8-1.0$ $\mathrm{ml}$ blood samples from each carbon dioxide-anaesthetized mouse were withdrawn by cardiac puncture using heparinized syringes. Blood samples were placed on wet ice for $30 \mathrm{~min}$ and centrifuged at $3000 \mathrm{rpm}$ for $10 \mathrm{~min}$ at $+4^{\circ} \mathrm{C}$ to obtain plasma. Brain and heart samples were dissected, weighed and immediately frozen in liquid nitrogen. Plasma and tissues were stored at $-80^{\circ} \mathrm{C}$ until analysis by LC-MS/MS preceded by a solid-liquid matrix extraction process. Briefly, tissue samples were homogenized in 10 volumes $(\mathrm{V} / \mathrm{W})$ of $0.1 \mathrm{M} \mathrm{KH}_{2} \mathrm{PO}_{4}$ buffer $\mathrm{pH}$ 7.4. Homogenates were vortexed and centrifuged at $3000 \mathrm{rpm}$ for $15 \mathrm{~min}$ at $+4{ }^{\circ} \mathrm{C}$. Plasma and tissue supernatants samples were extracted using 1-ml Oasis HLB SPE cartridges (Waters, Saint Quentin en Yvelines, France) preconditioned with $0.5 \mathrm{ml}$ of methanol, followed by 0.5 $\mathrm{ml}$ of water. Half millilitre of the processed sample was pulled through the cartridge before washing with $0.5 \mathrm{ml}$ of $5 \%$ methanol in water and elution with $0.25 \mathrm{ml}$ of methanol. The methanolic eluant was dried at $43^{\circ} \mathrm{C}$ under vacuum, and the dried residue was reconstituted with $100 \mu 1$ of LC mobile phase, and an aliquot of $20 \mu 1$ was injected into the LC-MS/MS system (Waters), a Quattro LC system equipped with an Alliance 2795 pump and an electrospray ionization (ESI) interface. The chromatographic separation was carried out on a X-Terra MS C18 reversed phase column $(1.5 \times 100 \mathrm{~mm}, 3.5 \mu \mathrm{m}$, Waters $)$ with a binary mobile phase $(0.02 \%$ trifluoroacetic acid in water) in isocratic conditions $(32 \%$, acetonitrile). The flow rate $(0.6 \mathrm{ml} / \mathrm{min})$ was split 1:6 and introduced into the ESI source. Argon was used as collision gas at collision energies of $15 \mathrm{eV}$ for BF2.649 and $20 \mathrm{eV}$ for BF30 (i.e. 1-[3-(4chlorophenyl)propyl]-4-phenylpiperazine, hydrochloride) used as internal standard. Ions of $\mathrm{m} / \mathrm{z} 296$ and 315 corresponding to the protonated molecules of BF2.649 and BF30, 
respectively, were selected as precursor ions. Peak area ratios of BF2.649/BF30 over an effective calibration range of 1 to $2000 \mathrm{ng} / \mathrm{ml}$ (with a limit of quantification of $1 \mathrm{ng} / \mathrm{ml}$ ) were used to determine plasma and tissue BF2.649 concentrations.

\subsection{Effect of BF2.649 on spontaneous locomotor activity}

Male Swiss mice (21-25 g, R. Janvier, le Genest St Isle, France) were introduced individually in infrared locomotor activity monitors (Imetronic, Pessac, France). Spontaneous horizontal locomotor activities were recorded continuously for $30 \mathrm{~min}$ (10 min intervals) before the administration of vehicle or one of the following drugs: ciproxifan (3 mg/kg, p.o.), BF2.649 (10 mg/kg, p.o.), MK-801 (0.25 mg/kg, i.p.) or diazepam (10 mg/kg, p.o.). Administration was performed either at about 9:00 a.m. for studies performed during the light-on phase or at about 6:00 p.m. for studies centred on the beginning of the light-off phase. Then mice were returned to their activity cage and locomotor activities were recorded over 3 hours by 10-min intervals.

\subsection{Effect of BF2.649 on methamphetamine-induced locomotor activation}

Male Swiss mice (35-40 g, R. Janvier, le Genest St Isle, France) received an intraperitoneal administration of vehicle or BF2.649 $(5 \mathrm{mg} / \mathrm{kg}) 30 \mathrm{~min}$ before their introduction in activity monitors (LE886 model, Letica Scientific Instruments, Spain). This detection system based on variation of electrical potential on a floor made of metallic bars allowed the detection of movement of paws. Spontaneous movements were recorded continuously for $90 \mathrm{~min}$ ( $5 \mathrm{~min}$ intervals) before they received an intraperitoneal administration of vehicle or methamphetamine $(0.75 \mathrm{mg} / \mathrm{kg})$. Then they were reintroduced in their activity cage and movements were recorded over 3.5 hours by 5 -min intervals. Experiments started at about 9:00 a.m. 


\subsection{Effect of BF2.649 on MK-801-induced locomotor activation}

Male Swiss mice (30-40 g, R. Janvier, le Genest St Isle, France) were introduced individually in activity monitors (LE886 model, Letica Scientific Instruments, Spain). Spontaneous movements were recorded continuously for $30 \mathrm{~min}$ ( $5 \mathrm{~min}$ intervals) before they received an intraperitoneal administration of vehicle or BF2.649 $(5 \mathrm{mg} / \mathrm{kg})$. Then they were reintroduced in their activity cage and, $60 \mathrm{~min}$ later, were challenged with MK-801 (0.2 mg/kg, i.p.). Movements were recorded over 3.5 hours by 5 -min intervals. Experiments started at about 9:00 a.m.

\subsection{Effect of BF2.649 on apomorphine-induced climbing behaviour}

Adult male Swiss mice (30-45 g, R. Janvier, le Genest St Isle, France) received vehicle or BF2.649 (5 mg/kg, i.p.) and were introduced individually in small cylindrical cages $(14 \mathrm{~cm}$ diameter, $14 \mathrm{~cm}$ high) with walls and tops of metal bars (2 mm diameter, $1 \mathrm{~cm}$ apart) for a 60min habituation period. Then apomorphine $(1.13 \mathrm{mg} / \mathrm{kg})$ was administered s.c. and mice were replaced within the test apparatus. Each animal was observed for $10 \mathrm{~s}$ every minute until 45 min post challenge. The climbing behaviour was scored as follows: 0 attributed to four paws on floor, 1 for one forepaw on grid (touching), 2 for both forepaws on grid (gripping) and 3 for all paws on grid (climbing) as described [16]. Experiments were carried out between 9:00 a.m. and 5:00 p.m. in a diffusely illuminated room maintained at $22 \pm 1^{\circ} \mathrm{C}$.

\subsection{Effect of BF2.649 on the prepulse inhibition deficit elicited by apomorphine}

Male Swiss mice (30-35 g, R. Janvier, Le Genest-St-Isle, France) were injected i.p. with vehicle or BF2.649 (3 mg/kg) followed $30 \mathrm{~min}$ later by an s.c. injection of vehicle $(0.1 \%$ ascorbic acid) or apomorphine $(10 \mathrm{mg} / \mathrm{kg})$. Five min later, mice were placed into the restraint 
cylinders of the startle chamber for a 5-min habituation period to the background noise (68 $\mathrm{dB})$. Startle stimulus trials of $120 \mathrm{~dB}$ intensity and $40 \mathrm{~ms}$ duration were applied, either alone or preceded by $30 \mathrm{~ms}$ with a prepulse of an intensity of 76,80 or $84 \mathrm{~dB}$ and $20 \mathrm{~ms}$ duration. Prepulse alone trials of 76,80 or $84 \mathrm{~dB}$ were also presented, as were trials containing no stimulus at all. A total of 10 trials of each type were performed in a pseudorandom order, with the intertrial interval varying in a random fashion from 8 to $22 \mathrm{~s}$. At the beginning of each test session, a 10-pulse alone trial $(120 \mathrm{~dB}, 40 \mathrm{~ms})$ was presented in blocks to scale down the initial startle response to a stable plateau. PPI was calculated as a percentage of this startle response using the formula:

$$
\frac{(\text { amplitude (pulse) }- \text { amplitude (prepulse/pulse) })}{\text { amplitude (pulse) }} \times 100
$$

Startle reactivity was measured using two SR-LAB startle chambers (San Diego Instruments, San Diego, CA, U.S.A.). The animal enclosures consisted of a Plexiglas restraint cylinder (3.7 $\mathrm{x} 12.8 \mathrm{~cm}$ long) fixed on a platform connected to a piezoelectric accelerometer that detected movement within the cylinder. Above the cylinder was a speaker capable of producing noise up to $120 \mathrm{~dB}$ attached to programmable audio controls. Audio stimuli were calibrated $( \pm$ $1 \mathrm{~dB}$ ) with a sound level meter (model 33 2055, RadioShack, Fort-Worth, USA). Startle platforms were calibrated (SR-LAB calibrator standardization unit) with less than 3\% variation between platforms. The animal enclosure was located in an illuminated, ventilated, and sound-attenuated chamber. All testing took place during the light-on phase.

\subsection{Effect of BF2.649 on the cortical EEG and sleep-wake cycle in mice}

Male adult C57BL6/J mice (27-33 g, Charles River, L'Arbresle, France) were chronically implanted with cortical and muscle electrodes to record electroencephalogram (EEG) and electromyogram (EMG), respectively, to monitor their sleep-wake cycle. Polygraphic 
recordings were started 15 days after surgery ( 5 days of recovery followed by 10 days of habituation to the recording cable). Animals were housed individually in a sound-proofed recording room maintained at appropriate ambient temperature $\left(22 \pm 1^{\circ} \mathrm{C}\right)$ on a $12 \mathrm{~h} \mathrm{light} / \mathrm{dark}$ cycle (light on at 7:00 a.m.), food and water being available at libitum. Polygraphic recordings were performed during 4 days to collect baseline qualitative and quantitative data of sleep-wake parameters in each animal. Then evaluation of responses to BF2.649 administered orally (10:00 a.m.) at 2.5, 5, 10 or $20 \mathrm{mg} / \mathrm{kg}$ was performed over $24 \mathrm{~h}$ recording sessions. Sleep-wake states included wakefulness (W), slow wave sleep (SWS) and paradoxical sleep (PS) were scored by successive $30 \mathrm{sec}$ epochs as previously described [17, $18]$.

\subsection{Effect of BF2.649 on cerebral amines and/or metabolites}

Male OF1 mice (\#25 g, Charles River, L’Arbresle, France) were treated between 08:00 and 09:00 a.m. with vehicle or BF2.649 (10 mg/kg, p.o.) before decapitation. Brain structures (prefrontal cortex, striatum) were rapidly dissected out on wet ice, frozen in liquid nitrogen and kept at $-20^{\circ} \mathrm{C}$ until assay. For analysis, prefrontal cortex and striatum were homogenized in $0.5 \mathrm{ml}$ and $1 \mathrm{ml}$, respectively, of a $0.4 \mathrm{~N}$ perchloric acid / $2.7 \mathrm{mM}$ EDTA solution. After centrifugation $\left(5000 \mathrm{rpm}, 15 \mathrm{~min}, 4^{\circ} \mathrm{C}\right.$ ), the supernatant was analyzed by HPLC coupled to an electrochemical detection. A 5- $\mu 1$ aliquot of the supernatant was directly injected into reversephase column (Atlantis $\mathrm{dC}_{18}, 2.1 \times 150 \mathrm{~mm}, 3 \mu \mathrm{m}$, Waters) with a mobile phase consisting of $3 \%$ methanol, $97 \%$ buffer containing $50 \mathrm{mM}$ citric acid, $70 \mu \mathrm{M}$ EDTA, $90 \mu \mathrm{M}$ octane sulfonic acid, $2.3 \mathrm{mM} \mathrm{NaCl}, \mathrm{pH} 2.9$ at a flow rate of $0.25 \mathrm{ml} / \mathrm{min}$. Eluates were quantified at $40^{\circ} \mathrm{C}$ with an amperometric detector set at $600 \mathrm{mV}$ (Waters 2465 electrochemical detector fitted with a $3 \mathrm{~mm}$ glassy carbon working cell with an in situ $\mathrm{Ag} / \mathrm{AgCl}$ reference electrode (ISAAC, Waters) and a $50 \mu \mathrm{m}$ spacer). Tissue concentrations of dopamine, DOPAC as well 
as 5-HIAA and 5-HT were determined and the corresponding ratio (DOPAC/dopamine, 5HIAA/5-HT) were calculated. In addition, the concentration of t-MeHA in brain tissues was determined by an enzymoimmunoassay performed on the perchloric acid supernatant as previously described [19].

\subsection{Animals}

Animals were housed in group under a 12-h light / dark cycle (lights on 7:00 a.m.) in a temperature $21 \pm 2{ }^{\circ} \mathrm{C}$ and $45 \pm 15 \%$ humidity-controlled environment with free access to food and water. Administrations were performed with drug preparations in either $1 \%$ methylcellulose for the oral route, or in $0.9 \% \mathrm{NaCl}$ for intravenous and intraperitoneal routes. All experiments carried out in the present study were conducted in accordance with international European ethical standards (86/609-EEC) and the French National Committee (décret 87/848) for the care and use of laboratory animals.

\subsection{Chemicals and drugs}

Drugs were expressed in equivalent of base except when indicated. Their sources were as follows: BF2.649 [1-\{3-[3-(4-chlorophenyl)propoxy]propyl\}piperidine, hydrochloride] and BF30 [1-[3-(4-chlorophenyl)propyl]-4-phenylpiperazine, hydrochloride] synthesis (Pr Schunack, Free University, Berlin, Germany or Interquim, Barcelona, Spain) will be described elsewhere. Ciproxifan was from Laboratoire Bioprojet (Paris, France). Diazepam was from Roche (Valium ${ }^{\circledR}$, Basel, Switzerland). Dopamine, DOPAC, 5-HIAA, 5-HT, tMeHA, apomorphine, methamphetamine and MK-801 (dilzocilpine) were from Sigma (Isle d'Abeau, France). All other chemicals were obtained from commercial sources and were of the highest purity available. 


\section{Results}

\subsection{Pharmacokinetics of BF2.649}

Mice receiving BF2.649 at a $10 \mathrm{mg} / \mathrm{kg}$ dose presented maximal concentrations $\left(\mathrm{C}_{\max }\right) 30 \mathrm{~min}$ after oral administration with $\mathrm{C}_{\max }$ values of $441 \pm 69 \mathrm{ng} / \mathrm{ml}$ in plasma, $10346 \pm 1099 \mathrm{ng} / \mathrm{g}$ in brain and $4092 \pm 527 \mathrm{ng} / \mathrm{g}$ in heart (Fig. 1). BF2.649 had a plasmatic elimination half-life of $\sim 120$ min. AUC values calculated for plasma, brain and heart were respectively of 1475 , 34686 and $13735 \mathrm{ng} . \mathrm{hr} / \mathrm{ml}$. These results demonstrated oral absorption of BF2.649 and high brain exposure, evidenced by $\mathrm{AUC}_{\text {brain }} / \mathrm{AUC}_{\text {plasma. and }} \mathrm{C}_{\max \text { brain }} / \mathrm{C}_{\max }$ plasma ratios of $\sim 23.5 \mathrm{in}$ both cases.

\subsection{Effect of BF2.649 on spontaneous and drug-induced motor activity}

The effect of BF2.649 on the spontaneous locomotor activity (LMA) was evaluated at the beginning of the dark phase and during the light-on phase. During the light-off phase period studied (Fig. $2 \mathrm{C}$ and D), control mice presented a cumulated LMA (123 \pm 13$)$ increased by $\sim+215 \%$ as compared to the corresponding value $(39 \pm 5)$ measured during the light-on phase (Fig. 2A and B). The two $\mathrm{H}_{3}$-receptor inverse agonist (ciproxifan and BF2.649 given respectively at 3 and $10 \mathrm{mg} / \mathrm{kg}$, p.o.) were without any significant effect on the locomotor activity during the two periods of time analyzed (e.g. whatever the wake/sleep phase). In contrast reference agents modified LMA in opposite manner: MK-801 (0.25 mg/kg, i.p.) elicited significantly an hyperlocomotion with a cumulated LMA values of $1072 \pm 156$ $(\mathrm{p}<0.0001)$ and $622 \pm 166(\mathrm{p}<0.0001)$ during the light-off and the light-on phases respectively, whereas diazepam $(10 \mathrm{mg} / \mathrm{kg}$, p.o.) reduced the LMA by $\sim 59 \%(\mathrm{p}=0.42)$ in the light-off phase and, although to a lower extent, (by $\sim 38 \%, p=0.89$ ) during the light-on phase. In the conditions of the test which were chosen to avoid any interference with noveltyinduced arousal, the effect of diazepam was not found to be significant. 
In the MK-801-induced hyperactivity test, BF2.649 was found to be without any significant effect on the spontaneous activity in habituated mice. In addition, the activity levels just before the methamphetamine and the MK-801 administrations were also rather similar and higher than the basal activity recorded in spontaneous locomotor experiments because of differences in testing conditions.

Methamphetamine $(0.75 \mathrm{mg} / \mathrm{kg}$, i.p. $)$ increased the activity with a cumulated movement value $(12998 \pm 2207)$ significantly enhanced by $\sim 154 \%(\mathrm{p}=0.001)$ as compared to control $(5121 \pm$ 733 ) (Fig. 3). BF2.649 reduced significantly by $\sim 63 \%(\mathrm{p}=0.029)$ the cumulated movements in animals challenged with this dose of methamphetamine but did not anymore affect hyperactivity induced by a higher methamphetamine dose ( 1 or $2 \mathrm{mg} / \mathrm{kg}$, data not shown). Administration of MK-801 in low dosage $(0.2 \mathrm{mg} / \mathrm{kg}$, i.p.) elicited a spontaneous hyperactivity with cumulated movement values of $11,916 \pm 1,273$ as compared to $2,151 \pm 360$ in controls $(\mathrm{p}<0.0001)$. The activity in the absence of MK-801 was not altered by BF2.649 (cumulated activity of $3267 \pm 1208, \mathrm{p}=0.57$ ) but BF2.649 pre-treatment significantly reduced (by $\sim 33 \%, p=0.032$ ) the MK-801-induced hyperactivity (Fig. 4).

\subsection{Effect of BF2.649 on the apomorphine-induced climbing behaviour}

A clear bell-shape response was observed when scoring climbing versus time following the sub-cutaneous administration of a $1.13 \mathrm{mg} / \mathrm{kg}$ dose of apomorphine (Fig. 5). Lower doses (0.5 and $1 \mathrm{mg} / \mathrm{kg}$ ) and higher doses (1.25 and $1.5 \mathrm{mg} / \mathrm{kg}$ ) of apomorphine were less effective in inducing a climbing behaviour (not shown). Whereas BF2.649 (5 mg/kg, i.p.) did not induce any climbing behaviour when given alone (not shown), it reduced although not significantly, $(p=0.27)$ the climbing behaviour elicited by apomorphine in mice (Fig. 5)

\subsection{Effect of BF2.649 on the prepulse inhibition deficit elicited by apomorphine}


BF2.649 (3 mg/kg, i.p.), apomorphine (10 mg/kg, s.c.) and their association had no significant effect on the amplitude of acoustic startle response when compared to controls $\left(\mathrm{F}_{3,28}=0.37\right.$, $p=0.77$ in one way ANOVA) (Fig. 6A). The two way ANOVA analysis evidenced that the drugs tested significantly affected PPI (treatment: $\mathrm{F}_{3.27}=3.65, \mathrm{p}=0.025$; prepulse intensity $\mathrm{F}_{3.54}=45.97, \mathrm{p}<0.001$; treatment-prepulse intensity interaction $\left.\mathrm{F}_{6.54}=2.30, \mathrm{p}=0.047\right) .$. Fisher LSD post-hoc analysis indicated that apomorphine significantly disrupted PPI $(p<0.05)$ and that BF2.649 significantly reduced the apomorphine-induced disruption $(p<0.05)$ at the prepulse intensity of $84 \mathrm{~dB}$. BF2.649 alone had no significant effect on PPI when compared to controls (Fig. 6B). At the two lowest prepulse intensities (76 and $80 \mathrm{~dB}$ ), the effect of BF2.649 did not reach significance but BF2.649 also tended to attenuate the deficit induced by apomorphine (Fig. 6B).

\subsection{Effect of BF2.649 on the cortical EEG and sleep-wake cycle in mice}

In mice, oral administration of BF2.649 caused a dose-dependent reduction of neocortical slow activity (at $\delta$ range $0.8-2.5 \mathrm{~Hz}$ ) and spindles $(8-15 \mathrm{~Hz}$ ) and an increase in power spectral density of neocortical fast rhythms ( $\beta$ and $\gamma$ bands, mainly $30-60 \mathrm{~Hz}$ ) resulting in a marked enhancement of cortical activation, i.e. low voltage and fast electrical activity with dominant waves in the $\beta$ and $\gamma$ bands (Fig. 7). As shown in an analysis of the sleep-wake states over 4 hours after BF2.649 administration (Fig. 8), the compound promoted dose-dependently the waking state with a significant increase of $\sim 34 \%$ and $\sim 80 \%$ in time spent awake for mice receiving respectively $10 \mathrm{mg} / \mathrm{kg}$ and $20 \mathrm{mg} / \mathrm{kg}$ of BF2.649 as compared with data obtained with vehicle treatment in the same mice. This increase in waking occurred at the expense of paradoxical and slow wave sleeps, which were reduced respectively by $17 \%$ and $16 \%$ at the dose of $10 \mathrm{mg} / \mathrm{kg}$ and by $58 \%$ and $35 \%$ at the dose of $20 \mathrm{mg} / \mathrm{kg}$ (Fig. 8). 


\subsection{Effect of BF2.649 on cerebral amines and/or metabolites}

The BF2.649-treated mice exhibited a higher DOPAC/dopamine ratio ( $+55 \%$ vs. vehicle, $\mathrm{p}=0.04$ ), an index of dopamine turnover rate, in prefrontal cortex, while no difference between vehicle- and BF2.649-treated groups were elicited in striatum $(p=0.12)$, cerebral cortex $(p=0.60)$ and hypothalamus $(p=0.77)$ (Table 1).. The effect of BF2.649 elicited on the serotonergic neuronal activities was limited only to a $15 \%$ increase $(p=0.005)$ of the ratio 5 HIAA/5-HT in the striatum without any significant effect in other tissues. As expected, BF2.649 induced a maximal increase in t-MeHA levels in both striatum and prefrontal cortex as well as in the other tissues (cortex and hypothalamus) investigated (Table 1). 


\section{Discussion}

BF2.649 appears as a potent inverse agonist at the human and, although slightly less so, at the rodent histamine $\mathrm{H}_{3}$ receptor, which activates cerebral histamine release in vivo at low oral dosage with ED50 dose of $1.6 \mathrm{mg} / \mathrm{kg}$ and a maximal effect elicited at $10 \mathrm{mg} / \mathrm{kg}$, p.o. [15] and 3 to $5 \mathrm{mg} / \mathrm{kg}$, i.p. (not shown). In agreement we find here that the drug displays a high degree of brain penetration in mice as judged by brain/plasma ratios of over 25 when either $\mathrm{C}_{\max }$ or AUC values are considered. It is noteworthy, however, that the present data, obtained using a LC-/MS/MS drug assay, led to plasma and tissue levels about 5-fold lower than corresponding values obtained by Ligneau et al. [15] using a radioreceptor assay. This apparent discrepancy can be easily explained by the lesser selectivity of the latter assay in which some metabolites of BF2.649 still displaying affinity at the $\mathrm{H}_{3}$ receptor cross react. In any case, the high brain/plasma ratio achieved by the compound seems a favourable feature for therapeutic applications inasmuch as the $\mathrm{H}_{3}$ receptor is almost exclusively expressed in brain $[20,21]$.

The major finding of the present studies, performed with a compound undergoing clinical trials, is that BF2.649 is active in several rodent models of "psychosis", which did not fulfil all the criteria of the complex human pathology, but are nevertheless generally considered to allow detection of the antipsychotic potential of new chemical entities.

The antagonism of amphetamine-induced motor activation in mice by BF2.649 was first described with the prototypical $\mathrm{H}_{3}$-receptor antagonist/inverse agonist thioperamide [22] but also found later with other compounds of the same pharmacological class. The latters do not change spontaneous locomotor activity when they are used alone [22, 23, 24] and do not induce locomotor sensitization [25]. However, the locomotor activation elicited in rat and mouse by various direct or indirect dopaminergic agonists such as amphetamine, methamphetamine and apomorphine is attenuated by thioperamide and ciproxifan $[22,1]$. 
Also ciproxifan, a potent $\mathrm{H}_{3}$-receptor antagonist, significantly decreases the stereotypies induced in mice by methamphetamine and apomorphine [26]. Consistent with these findings, the effect of methamphetamine on locomotor activity and stereotypic behaviour was less pronounced in $\mathrm{H}_{3}$-receptor knockout mice [27]. The mechanism underlying this functional antagonism of behavioural responses elicited by direct or indirect dopamine agonists is far from clear. A direct antagonism at dopamine receptors cannot be invoked in view of the high degree of pharmacological specificity of BF2.649 [15]; also this drug effect consisted in a partial decrease of the response to the dopamine agonists, which was, even, not significant in the case of the apomorphine-induced climbing behaviour.

In another animal model of psychosis $[28,29]$, i.e. the locomotor hyperactivity induced by the NMDA-receptor antagonist MK-801, the activity was also markedly attenuated by BF2.649, as it is by other $\mathrm{H}_{3}$-receptor antagonists/inverse agonists [9]. Finally we assessed the drug effect on prepulse inhibition (PPI) of the acoustic startle response in mice. This model is extensively used to analyze sensorimotor gating deficits, considered as cardinal signs of schizophrenia and is, therefore, a valuable test to predict antipsychotic properties of new drugs. Among the various manipulations known to disrupt PPI, dopamine agonists are the most frequently used [30]. However, although dopaminergic agonists consistently disrupt PPI, the effects of apomorphine have been found to differ in potency between rats and mice. In agreement with previous studies [31, 32], we observed that apomorphine disrupted PPI in mice when given at a sufficiently high dose, i.e. $10 \mathrm{mg} / \mathrm{kg}$, in the present study. In addition, the prepulse and stimulus parameters have been shown to influence the sensitivity to drugs effects. As previously reported [33], we found that a short inter-stimulus interval (30 ms) coupled to a high prepulse intensity $(84 \mathrm{~dB})$, was optimal to produce a robust disruption of PPI (up to $92 \%$ ) with apomorphine in mice. In these optimal conditions, BF2.649 suppressed almost totally the apomorphine-induced disruption and restored PPI. Recently, other $\mathrm{H}_{3}-$ 
receptor antagonists/inverse agonists were also shown to improve gating deficits occurring naturally in DBA/2 mice $[34,35]$, suggesting that this improvement is a drug class effect.

Taken together, the present findings on several rodent models of schizophrenia certainly support the therapeutic potential of $\mathrm{H}_{3}$-receptor antagonists/inverse agonists such as BF2.649 for the symptomatic treatment of schizophrenia.

Two other observations are of interest when considering the potential of this drug class in this therapeutic area. First, we show here that BF2.649 activates dopamine turnover in the prefrontal cortex but not in the striatal complex, a pattern characteristic of the mode of action of atypical antipsychotics which are assumed to counteract the "hypofrontality" well documented in the disease [36]. Again this neurochemical pattern already described in microdialysis experiments [35] seems to represent a drug class effect. Second, the cognitive deficit is certainly one of the symptoms which are the most resistant to current medications. In the case of BF2.649, a promnesiant effect accompanied with a shift of the EEG patterns towards high frequency waves, characteristic of cortical activation and a pro-attention effect, was previously demonstrated in cats [15] and is also observed here to accompany the wakening effect of the drug in mice.

In conclusion, the present findings with BF2.649, together with recent similar observations with other $\mathrm{H}_{3}$-receptor antagonists/inverse agonists, may indicate a potential for these drugs to represent a new class of antipsychotics with an original therapeutic profile. 


\section{Acknowledgments.}

The authors thank the experimental and technical contributions of C. Buda, J.-P. Sastre and G. Guidon. 


\section{Legends}

Fig. 1 - Plasma, brain and heart concentration profiles of BF2.649 in mice after oral administration of BF2.649 $(10 \mathrm{mg} / \mathrm{kg})$. Each point represents the mean value \pm S.D. from five male animals.

Fig. 2 - Effect of ciproxifan (3 mg/kg, p.o.) and BF2.649 (10 mg/kg, p.o.) on spontaneous locomotor activity and cumulated locomotor activity during light-on (A and B) and light-off (C and D) periods in mice. Means \pm S.E.M. of 12 to 20 mice for vehicle, ciproxifan (CPX) and BF2.649. Means \pm S.E.M. of 8 to 12 mice for MK- $801(0.25 \mathrm{mg} / \mathrm{kg}$, i.p. $)$ and 4 to 8 for diazepam (10 mg/kg, p.o.). Statistical comparison of cumulated locomotor activity over the first 180 min of challenge was performed by ANOVA (light on $\mathrm{F}_{4,43}=15.12$, $\mathrm{p}<0.0001$; light off $\mathrm{F}_{4,75}=53.42, \mathrm{p}<0.0001$ ) followed by post-hoc PLSD Fisher test $(* * * \mathrm{p}<0.001$ vs. vehicle).

Fig. 3 - Effect of BF2.649 on methamphetamine-induced motor hyperactivity in mice. Vehicle or BF2.649 (5 mg/kg, i.p.) were given 2 hours before methamphetamine $(0.75 \mathrm{mg} / \mathrm{kg}$, i.p.) administration (arrow). Statistical comparison of cumulated movements (mean \pm S.E.M. of 7 to 8 mice, right panel) over the first 60 min of challenge was performed by ANOVA $\left(F_{2,19}=7.66, p=0.036\right)$ followed by post-hoc PLSD Fisher test $(* * p<0.01$ vs. vehicle, $\# p<0.05$ vs. methamphetamine).

Fig. 4 - Effect of BF2.649 on MK-801-induced motor hyperactivity in mice. Vehicle or BF2.649 (5 mg/kg, i.p.) were given 1 hour before MK-801 (0.2 mg/kg, i.p.) administration (arrow). Statistical comparison of cumulated movements (mean \pm S.E.M. of 7 to 8 mice, right panel) over the first 60 min of challenge was performed by ANOVA $\left(F_{3,19}=15.87, p<0.0001\right)$ followed by post-hoc PLSD Fisher test (*** $\mathrm{p}<0.001$ vs. vehicle, $\# \mathrm{p}<0.01$ vs. MK-801). 
Fig. 5 - Effect of BF2.649 on the apomorphine-induced climbing behaviour in mice. Vehicle or BF2.649 (5 mg/kg, i.p.) were given 1 hour before apomorphine (1.13 mg/kg, s.c.). Climbing behaviour was scored as follows: 0 attributed to four paws on floor, 1 for one forepaw on grid (touching), 2 for both forepaws on grid (gripping) and 3 for all paws on grid (climbing). Time-course of total behavioural scores (left panel) and the percentage of each behaviours observed over $45 \mathrm{~min}$ (right panel) are presented. Results were analyzed by ANOVA $\left(\mathrm{F}_{1,22}=1.279, \mathrm{p}=0.27\right)$ followed by a PLSD Fisher post-hoc test $(\mathrm{n}=12$ mice per group).

Fig. 6 - Effect of BF2.649 (3 mg/kg, i.p.) administered $30 \mathrm{~min}$ prior to apomorphine (10 $\mathrm{mg} / \mathrm{kg}$, s.c.) on (A) the startle amplitude during pulse-alone trials in mice (B) the deficit of prepulse inhibition (PPI) induced by apomorphine in the same mice after three different prepulse intensity levels $(76,80$ and $84 \mathrm{~dB})$. Results are expressed as mean \pm S.E.M. $(\mathrm{n}=7-9$ mice per group). ${ }^{*} \mathrm{p}<0.05,{ }^{\S} \mathrm{p}<0.05$ when compared to the vehicle group or the apomorphinetreated group, respectively (two way ANOVA followed by Fisher LSD post-hoc test).

Fig. 7 - Effects of BF2.649 on the cortical EEG and sleep-wake cycles in the mouse. Examples of cortical EEG power spectral density $\left(\mathrm{mV}^{2}\right)$ in different frequency bands and sleep-wake cycle $1 \mathrm{hr}$ before and up to $3 \mathrm{hr}$ after oral administration of BF2.649 (arrow, 5 or $10 \mathrm{mg} / \mathrm{kg}$ ) are given. Note, that BF2.649 elicited a waking state accompanied by a suppression of cortical slow frequency activity (at $\delta$ range: $0.8-2.5 \mathrm{~Hz}$ ) and spindle $(8-15 \mathrm{~Hz})$ and a marked increase in fast rhythms $(30-60 \mathrm{~Hz})$. Abscissa, time in hours, ordinate, sleepwake stages (PS, paradoxical sleep; SWS, slow wave sleep; W, wakefulness). 
Fig. 8 - Effects of BF2.649 on the sleep-wake cycles in mice. Sleep-wake states (PS, paradoxical sleep; SWS, slow wave sleep; W, wakefulness) were analyzed for 4 hours after oral administration of vehicle or BF2.649 (2.5, 5, 10 and $20 \mathrm{mg} / \mathrm{kg})$. Each mouse received successively the vehicle and the different BF2.649 doses with a 5-day wash-out period between each administration. Results were analyzed by ANOVA (W: $\mathrm{F}_{4,30}=9.715, \mathrm{p}<0.0001$; SWS: $F_{4,30}=7.980, p=0.0002 ; P S: F_{4,30}=5.955, p=0.0012$ ) followed by a Dunnett's t test (means \pm S.E.M. of 7 mice, $* * \mathrm{p}<0.01, * * * \mathrm{p}<0.001$ vs. placebo). 


\section{REFERENCES}

[1] Morisset S, Pilon C, Tardivel-Lacombe J, Weinstein D, Rostene W, Betancur C et al. Acute and chronic effects of methamphetamine on tele-methylhistamine levels in mouse brain: selective involvement of the $\mathrm{D}(2)$ and not $\mathrm{D}(3)$ receptor. J Pharmacol Exp Ther 2002;300:621-8.

[2] Sautel F, Griffon N, Sokoloff P, Schwartz JC, Launay C, Simon P et al. Nafadotride, a potent preferential dopamine D3 receptor antagonist, activates locomotion in rodents. J Pharmacol Exp Ther 1995;275:1239-46.

[3] Bouthenet ML, Martres MP, Sales N, Schwartz JC. A detailed mapping of dopamine D-2 receptors in rat central nervous system by autoradiography with [125I]iodosulpride. Neuroscience 1987;20:117-55.

[4] Ericson H, Blomqvist A, Kohler C. Brainstem afferents to the tuberomammillary nucleus in the rat brain with special reference to monoaminergic innervation. J Comp Neurol 1989;281:169-92.

[5] Schwartz JC, Arrang JM, Garbarg M, Gulat-Marnay C, Pollard H. Modulation of histamine synthesis and release in brain via presynaptic autoreceptors and heteroreceptors. Ann N Y Acad Sci 1990;604:40-54.

[6] Ito C, Onodera K, Sakurai E, Sato M, Watanabe T. Effects of dopamine antagonists on neuronal histamine release in the striatum of rats subjected to acute and chronic treatments with methamphetamine. J Pharmacol Exp Ther 1996;279:271-6. 
[7] Itoh Y, Oishi R, Nishibori M, Saeki K. Phencyclidine and the dynamics of mouse brain histamine. J Pharmacol Exp Ther 1985;235:788-92.

[8] Itoh Y, Oishi R, Nishibori M, Saeki K. Comparison of effects of phencyclidine and methamphetamine on body temperature in mice: a possible role for histamine neurons in thermoregulation. Naunyn Schmiedebergs Arch Pharmacol 1986;332:293-6.

[9] Faucard R, Armand V, Heron A, Cochois V, Schwartz JC, Arrang JM. N-methyl-Daspartate receptor antagonists enhance histamine neuron activity in rodent brain. $\mathrm{J}$ Neurochem 2006;98:1487-96.

[10] Prell GD, Green JP, Kaufmann CA, Khandelwal JK, Morrishow AM, Kirch DG et al. Histamine metabolites in cerebrospinal fluid of patients with chronic schizophrenia: their relationships to levels of other aminergic transmitters and ratings of symptoms. Schizophr Res $1995 ; 14: 93-104$.

[11] Nakai T, Kitamura N, Hashimoto T, Kajimoto Y, Nishino N, Mita T et al. Decreased histamine $\mathrm{H} 1$ receptors in the frontal cortex of brains from patients with chronic schizophrenia. Biol Psychiatry 1991;30:349-56.

[12] Rauscher FP, Nasrallah HA, Wyatt RJ. Cutaneous histamine response in schizophrenia. J Clin Psychiatry 1980;41:44-51. 
[13] Iwabuchi K, Ito C, Tashiro M, Kato M, Kano M, Itoh M et al. Histamine H1 receptors in schizophrenic patients measured by positron emission tomography. Eur Neuropsychopharmacol 2005;15:185-91.

[14] Arrang JM, Schwartz JC. Histamine and schizophrenia. In: Anissa Abi-Dargham and Olivier Guillin, editors. Integrating the Neurobiology of Schizophrenia. San Diego CA: Elsevier Inc., in press

[15] Ligneau X, Perrin D, Landais L, Camelin JC, Calmels T, Berrebi-Bertrand I et al. BF2.649, a non-imidazole inverse agonist/antagonist at the human histamine $\mathrm{H} 3$ receptor: preclinical pharmacology. J Pharmacol Exp Ther 2006; in press.

[16] Protais P, Costentin J, Schwartz JC. Climbing behavior induced by apomorphine in mice: a simple test for the study of dopamine receptors in striatum. Psychopharmacology (Berlin) 1976;50:1-6.

[17] Valatx JL, Bugat R. Genetic factors as determinants of the waking-sleep cycle in the mouse. Brain Res 1974;69:315-30.

[18] Parmentier R, Ohtsu H, Djebbara-Hannas Z, Valatx JL, Watanabe T, Lin JS. Anatomical, physiological, and pharmacological characteristics of histidine decarboxylase knock-out mice: evidence for the role of brain histamine in behavioral and sleep-wake control. J Neurosci 2002;22:7695-711. 
[19] Ligneau X, Lin JS, Vanni-Mercier G, Jouvet M, Muir JL, Ganellin CR et al.

Neurochemical and behavioral effects of ciproxifan, a potent histamine H3-receptor antagonist. J Pharmacol Exp Ther 1998;287:658-66.

[20] Chen J, Liu C, Lovenberg TW. Molecular and pharmacological characterization of the mouse histamine H3 receptor. Eur J Pharmacol 2003;467:57-65.

[21] Lovenberg TW, Pyati J, Chang H, Wilson SJ, Erlander MG Cloning of rat histamine H(3) receptor reveals distinct species pharmacological profiles. J Pharmacol Exp Ther 2000;293:771-8.

[22] Clapham J, Kilpatrick GJ. Thioperamide, the selective histamine H3 receptor antagonist, attenuates stimulant-induced locomotor activity in the mouse. Eur J Pharmacol 1994;259:10714.

[23] Imaizumi M, Onodera K. The behavioral and biochemical effects of thioperamide, a histamine H3-receptor antagonist, in a light/dark test measuring anxiety in mice. Life Sci $1993 ; 53: 1675-83$.

[24] Pillot C, Ortiz J, Heron A, Ridray S, Schwartz JC, Arrang JM. Ciproxifan, a histamine H3-receptor antagonist/inverse agonist, potentiates neurochemical and behavioral effects of haloperidol in the rat. J Neurosci 2002;22:7272-80. 
[25] Komater VA, Browman KE, Curzon P, Hancock AA, Decker MW, Fox GB. H3 receptor blockade by thioperamide enhances cognition in rats without inducing locomotor sensitization. Psychopharmacology (Berl) 2003;167:363-72.

[26] Sadakhom C, Frances H and Arrang JM. Ciproxifan, a histamine H3-receptor antagonist/inverse agonist, modulates methamphetamine- and apomorphine-induced stereotyped behaviors in mice. In preparation.

[27] Toyota H, Dugovic C, Koehl M, Laposky AD, Weber C, Ngo K et al. Behavioral characterization of mice lacking histamine $\mathrm{H}(3)$ receptors.

Mol Pharmacol 2002;62:389-97. Erratum in: Mol Pharmacol 2002;62:763.

[28] Andine P, Widermark N, Axelsson R, Nyberg G, Olofsson U, Martensson E et al. Characterization of MK-801-induced behavior as a putative rat model of psychosis. $\mathrm{J}$ Pharmacol Exp Ther 1999;290:1393-408.

[29] Carlsson M, Carlsson A. Interactions between glutamatergic and monoaminergic systems within the basal ganglia--implications for schizophrenia and Parkinson's disease. Trends Neurosci 1990;13:272-6.

[30] Geyer MA, Krebs-Thomson K, Braff DL and Swerdlow NR. Pharmacological studies of prepulse inhibition models of sensorimotor gating deficits in schizophrenia: a decade in review. Psychopharmacology (Berl) 2001;156:117-54. 
[31] Curzon P and Decker MW. Effects of phencyclidine (PCP) and (+)MK-801 on sensorimotor gating in CD-1 mice. Prog Neuropsychopharmacol Biol Psychiatry $1998 ; 22: 129-46$.

[32] Dulawa SC and Geyer MA. Psychopharmacology of prepulse inhibition in mice. Chin J Physiol 1996;39:139-46.

[33] Varty GB, Walters N, Cohen-Williams M and Carey GJ. Comparison of apomorphine, amphetamine and dizocilpine disruptions of prepulse inhibition in inbred and outbred mice strains. Eur J Pharmacol 2001;424:27-36.

[34] Browman KE, Komater VA, Curzon P, Rueter LE, Hancock AA, Decker MW and Fox GB. Enhancement of prepulse inhibition of startle in mice by the $\mathrm{H}_{3}$ receptor antagonists thioperamide and ciproxifan. Behav Brain Res 2004;153:69-76.

[35] Fox GB, Esbenshade TA, Pan JB, Radek RJ, Krueger KM, Yao BB et al. Pharmacological Properties of ABT-239 [4-(2-\{2-[(2R)-2-Methylpyrrolidinyl]ethyl $\}-$ benzofuran-5-yl)benzonitrile]: II. Neurophysiological characterization and broad preclinical efficacy in cognition and schizophrenia of a potent and selective histamine $\mathrm{H} 3$ receptor antagonist. J Pharmacol Exp Ther 2005;313:176-90.

[36] Meltzer HY. What's atypical about atypical antipsychotic drugs? Curr Opin Pharmacol 2004;4:53-7. 